\title{
In-vitro evaluation of some Indian lichens against human pathogenic bacteria
}

\author{
Srivastava $\mathbf{P}^{1}$, Logesh $\mathrm{AR}^{2}$, Upreti DK ${ }^{2}$, Dhole $\mathbf{T N}^{3}$ and Srivastava $\mathrm{A}^{4}$ \\ ${ }^{I}$ Department of Botany, Dr. R.M.L. Avadh University, Faizabad, India \\ ${ }^{2}$ Lichenology laboratory, Plant Biodiversity Conservation Biology and Herbarium Division, CSIR-National Botanical \\ Research Institute, Lucknow, India \\ ${ }^{3}$ Department of Microbiology, Sanjay Gandhi Post Graduate Institute of Medical Sciences, Lucknow, India \\ ${ }^{4}$ Department of Pathology \& Microbiology, Saraswati Dental \& Medical College, Lucknow, India \\ Email: upretidk@rediffmail.com
}

Srivastava P, Logesh AR, Upreti DK, Dhole TN, Srivastava A 2013 - In-vitro evaluation of some Indian lichens against human pathogenic bacteria. Mycosphere 4(4), 734-743, Doi 10.5943/mycosphere/4/4/10

\begin{abstract}
Antimicrobial activity of the acetone, methanol and ethanol extracts of some common lichen species such as Usnea longissima Ach., Everniastrum cirrhatum (Fr.) Hale, Peltigera polydactylon (Neck.) Hoffm. and Sulcaria sulcata (Lév.) Bystr. ex Brodo \& D. Hawksw., were screened in vitro against six clinically important pathogenic bacteria, Staphylococcus aureus, Streptococcus faecalis, Bacillus cereus, Pseudomonas aeruginosa, Salmonella typhimurium and Escherichia coli by Kirby-Bauer technique of disc diffusion method. Minimum inhibitory concentration was taken out by Broth micro dilution method according to the NCCLS guidelines. Acetone, methanol and ethanol extracts of the investigated lichens showed relatively strong antimicrobial activity against all the gram positive bacteria and two gram negative bacteria. It was found that the inhibition zone of tested bacteria against lichen extracts varied between $7.6-30.7$ mm diameters. The lowest MIC value was observed to be as low as $6.25 \mu \mathrm{g} / \mathrm{ml}$ against $B$. cereus of $U$. longissima. Generally the lichen extracts tested demonstrated antimicrobial effect which suggests a possibility of their use in treatment of various diseases caused by these and similar microorganisms.
\end{abstract}

Key words - Kirby-Bauer method - Lichenized fungi - MIC - pathogenic bacteria.

\section{Introduction}

Lichens are composite organisms consisting of symbiotic association of a fungus (the mycobiont) with a photosynthetic partner (the photobiont or phycobiont), usually either a green alga or cyanobacterium. Lichens are unique in nature and physiology because they look and behave quite differently from their component organisms. Lichens produce a wide range of organic compounds that can be grouped as primary metabolites and secondary metabolites (Elix 1996). Primary metabolites such as proteins, lipids, carbohydrates, and some other organic compounds are produced by both the partners and are needed for the lichen's metabolism and structure. Secondary metabolites are produced by the fungus alone and secreted onto the surface of lichen's hyphae either in amorphous forms or as crystals. The secondary metabolites include aliphatic, 
cycloaliphatic, aromatic and terpenic components are extra cellular products of relatively low molecular weight usually insoluble in water and can be extracted into organic solvents (Ötzürk et al. 1999). They make even more than $30 \%$ of the dry mass of thalus (Galun 1988). Up till now, about 350 biologically active secondary metabolites of lichens have been discovered and approximately 200 have been characterized (Chand et al. 2009, Tay et al. 2004). Lichen secondary metabolites have been investigated mostly for chemotaxonomic purposes and in connection with their potential as phytomedicines and natural biopesticides (Dayan and Romagni, 2001). Many lichens have been used for human or animal nutrition and used as dyes, perfumes, in preparation of alcohol and in the pharmaceutical industries (Kirmizigül et al. 2003, Richardson 1988, Romagni 2002). Lichen metabolites exert a wide variety of biological actions including antibiotic, antimycobacterial, antiviral, antiinflammatory, analgesic, antipyretic, antiproliferative and cytotoxic effects (Muller K. 2001). A number of lichen species are listed as having use as in folk medicine for treatment of stomach diseases, diabetes, whooping cough, pulmonary tuberculosis, cancer treatment and skin diseases (Baytop 1999, Huneck 1999, Richardson 1991). Medicinal activities of some lichens and their components are known, such as: antiviral, anti-tumor, antiinflammatory, analgesic, antipyretic, antiproliferative and antiprotozoal (Lawrey 1986, Halama and Van Haluvin 2004 and Huneck 1999). However, only very limited numbers of lichen substances have been screened only very limited numbers of lichen substances have been screened for their biological activities and their therapeutic potential in medicine. This is certainly due to the difficulties encountered in identification of the species, collection of bulk quantities, and the isolation of pure substances for structure determination and testing activity. Recently, possibility for by passing some of these former difficulties have arisen by the introduction of new techniques. This includes axenic cultivation for production of the genuine compounds or new ones, extraction of focused compounds, or synthesis of natural products or their derivatives for testing (Boustie and Grube 2005).

According to one estimate, $50 \%$ of all lichens have antibiotic properties (Sharnoff 1997). The development and spread of microbial resistance to the available antibiotics has prompted investigators to study antimicrobial substances from other sources. India being a mega diversity country exhibit rich diversity and luxuriance of lichens together with other group of plants. A number of vascular plants from the country are known having their potential medicinal use; however, so far the studies and enumeration of medicinal non vascular plants are not available from the country. In India, few studies regarding use of lichens against plant pathogen are available (Tiwari et al. 2011a, Tiwari et al. 2012b). Since, there has not been much work done on the antimicrobial activity of Indian lichens, especially against human pathogens. Thus the aim of the present study was to conduct in vitro evaluation of antibacterial activity with acetone, ethanol and aqueous extracts from the lichens against human pathogenic bacteria.

\section{Materials \& Methods}

\section{Collection and identification of lichens}

The lichen species were collected from different parts of the Himalayas in Uttarakhand and Himachal Pradesh. Lichen specimens were air dried at room temperature and identified by studying their morphology, anatomy and chemistry and authenticated using the standard literatures (Awasthi 2007, Orange et al. 2001). The voucher specimens are deposited in herbarium of National Botanical Research Institute, Lucknow (LWG).

\section{Extraction}

For extraction, air-dried lichen samples were ground, then $10 \mathrm{~g}$ portions were taken and added to $100 \mathrm{ml}$ of solvents of acetone, ethanol and methanol. The mixtures were sonicated for 30 minutes, then left at room temperature for seven days and flasks were sealed with parafilm so that the solvent cannot evaporate. The extracts were filtered over Whatman No 1 filter paper, and the filtrates were sterilized by membrane filtration using $0.45 \mu \mathrm{m}$ pore size filters. The extracts were 
then evaporated to dryness under reduced pressure and re-dissolved in respective solvents to attain the required concentration $0.2 \mathrm{mg} / \mathrm{ml}$ for antibacterial screening. These extracts were kept at $4{ }^{\circ} \mathrm{C}$ till used.

\section{Specimens used in the present study}

Fig.1

1. Everniastrum cirrhatum (Fr.) Hale.

India - Uttarakhand, Pithoragarh district, Narayan Swami Ashram. 02.11.2009, D.K. Upreti \& al, 09-013411-LWG.

2. Peltigera polydactylon (Neck.) Hoffm.

India - Uttarakhand, Pithoragarh district, Munsiyari, Khuliya top. 31.10.2009. D.K. Upreti \& al., 09-023666-LWG.

3. Sulcaria sulcata (Lév.) Bystr. ex Brodo

India - Uttarakhand, Pithoragarh district, Munsiyari, Khuliya Top, 17.11.2006. Y. Joshi \& R. Bajpai. 06-006935-LWG.

\section{Usnea longissima Ach.}

India - Uttarakhand, Pithoragarh district, Narayan Swami Ashram. 02.11.2009. D.K. Upreti \& al., 09-012179-LWG.
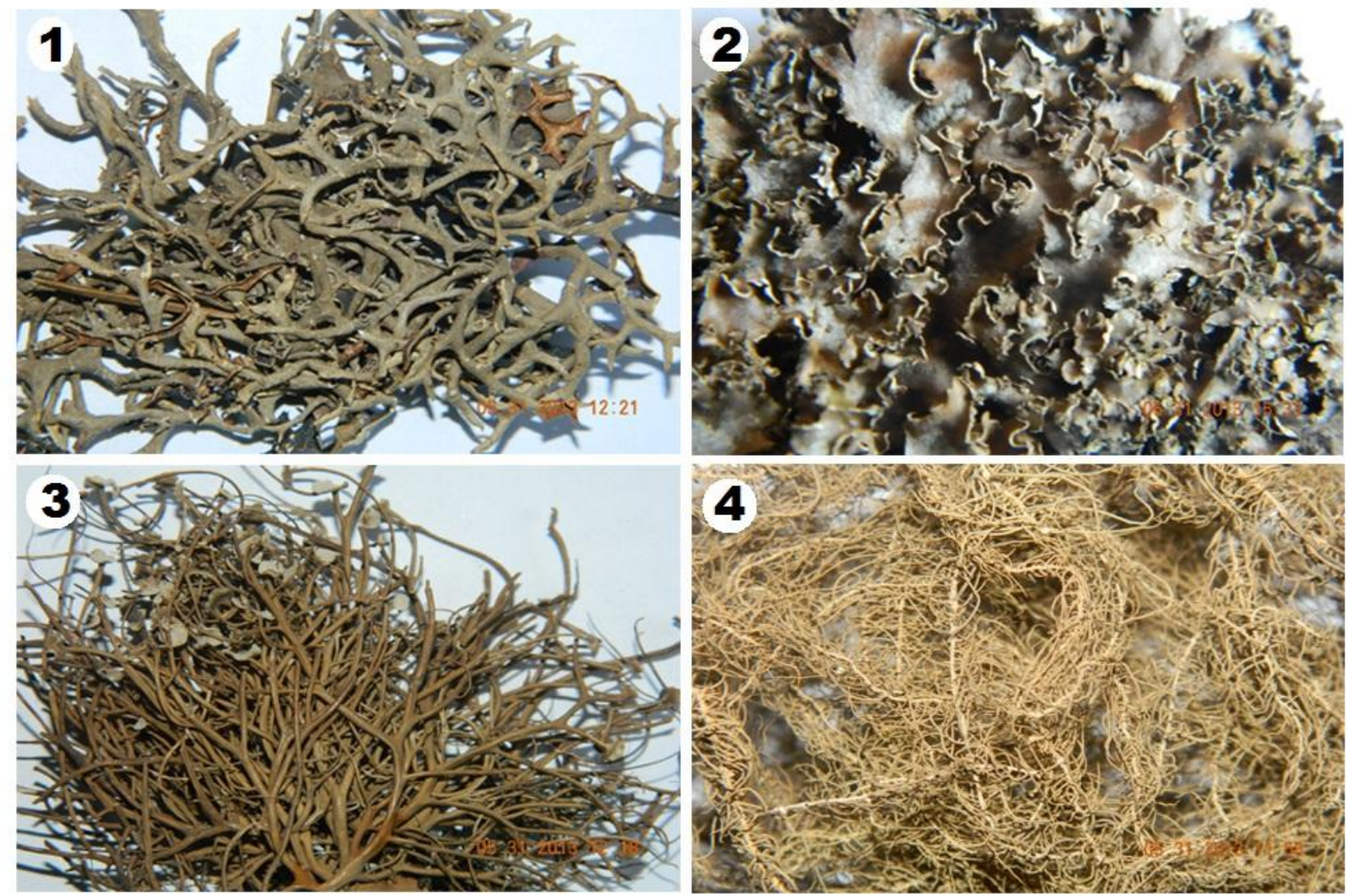

Fig. 1 - 1 Everniastrum cirrhatum (Fr.) Hale; 2 Peltigera polydactylon (Neck.) Hoffm.; 3 Sulcaria sulcata (Lév.) Bystr. ex Brodo; 4 Usnea longissima Ach. 


\section{Identification of lichen acids}

To identify the lichen substances present, the extracted lichen crude extracts were dissolved in acetone to a final concentration of $1 \mathrm{mg} / \mathrm{ml}$. The crude extracts were then spotted on silica gel thin layer chromatography (TLC) plates (silica gel 60 F254 aluminum plates, Merck) and run in solvent systems A (36:9:1 toluene/dioxane/glacial acetic acid). The plates were kept for air drying at room temperature. Before spraying, the dried plates were examined in day light for pigments and for fluorescence or quenching under short and long wave length ultraviolet (U.V) light. Subsequently, each TLC plate was then sprayed with $10 \%$ sulfuric acid and heated at $110^{\circ} \mathrm{C}$ for 10 minutes to visualize the lichen substances (Santos and Mondragon 1969). The Rf values for each spot were determined and compared with selected lichen compound standards: (1) norstictic acid, (2) usnic acid, (3) salazinic acid, (4) caperatic : usnic acid, 25:1, (5) protocetraric acid, (6) stictic : constictic acid, 2:1, (7) diffractaic acid, (8) barbatic acid, and (9) galbinic acid. The lichen acids standards were generously provided by Prof. Dr. Jack A. Elix, Australian National University, Canberra, Australia.

\section{Antibacterial activity of lichen extracts}

The antimicrobial activity of lichen extracts against tested bacteria was determined employing Kirby-Bauer technique of disk diffusion method (Bauer et al. 1966, NCCLS 1993) The lichen crude extracts were then tested for their inhibitory activities against representative test bacterial gram-positive bacteria such as Staphylococcus aureus (ATCC 25923), Streptococcus faecalis (ATCC 33186) and Bacillus cereus (ATCC 14579); gram-negative bacteria such as Escherichia coli (ATCC 25922), Pseudomonas aeruginosa (ATCC 29853), Salmonella typhimurium (ATCC 13311). Bacterial cell suspension was prepared from a 24-hour old culture, adjusted to $0.5 \mathrm{McF}$ arland standard, and swabbed on petri plates pre-filled with $25 \mathrm{ml}$ MuellerHinton Agar (MHA, Hi-Media). Antibiotic disks (Whatmann) measuring $6 \mathrm{~mm}$ in diameter were then placed onto the inoculated MHA plates (two disks per plate). To determine the sensitivity of lichen crude extracts, to each paper disk $10 \mu \mathrm{l}$ of $0.2 \mathrm{mg} / \mathrm{ml}$ concentration of lichen crude extract was added .The positive control were Gentamycin (for gram positive bacteria) and Ceftriaxone (for gram negative bacteria) and the negative control were the solvents acetone, methanol, ethanol respectively. Plates were then incubated at $37^{\circ} \mathrm{C}$ for $18-24 \mathrm{hrs}$. Following incubation, zones of inhibition including paper disks were then measured with a ruler and recorded.

The minimal inhibitory concentration (MIC) of the crude extract was determined by micro dilution techniques in Mueller-Hinton Broth (MHB), according to National Committee for Clinical Laboratory Standard, USA guidelines (NCCLS, 2002). A series of two fold dilutions with concentrations ranging from $200 \mu \mathrm{g} / \mathrm{ml}$ to $0.195 \mu \mathrm{g} / \mathrm{ml}$ of extract was used in the experiment against $S$. aureus, $S$. faecalis and B. cereus, $P$. aeruginosa, and E. coli. The starting solutions of extracts and component were obtained by measuring a certain quantity of extract and dissolving it in dimethylsulphoxide (DMSO). Two-fold dilutions of extracts and components were prepared in Mueller-Hinton broth (MHB) for bacterial cultures. The inoculates were prepared in the same medium at a density adjusted to a $0.5 \mathrm{McFarland}$ turbidity standard colony forming units, and diluted 1:10 for the broth micro dilution procedure .Then $100 \mu 1$ of diluted extracts and $100 \mu 1$ of bacterial suspensions were dispensed in 96 well sterile microtitre plate. The microtitre plates were incubated at $37^{\circ} \mathrm{C}$ and MIC was determined after $24 \mathrm{~h}$ of incubation. The MIC was determined by establishing visible growth of the microorganisms. The boundary dilution without any visible growth was defined as the MIC for the tested microorganism at the given concentration. Untreated bacteria were taken as Positive control and MHB was taken as negative control. All experiments were performed in triplicate.

The results of the antibacterial screening for disc diffusion assay are expressed as mean \pm SD of three replicates in each test and for MIC, the boundary dilution without any visible growth was defined as the MIC for the tested microorganism at the given concentration. 


\section{Results}

\section{Identification of lichen compounds}

The results of thin layer chromatography showed that lichen substances were present in all the four lichens used for the study. Usnea longissima showed presence of four compounds; stictic acid complex at $R f$ class 3, barbatic acid at $R f$ class 4, diffractic acid at $R f$ class 4 and usnic acid at $R \mathrm{f}$ class 6. Everniastrum cirrhatum shown salazinic acid at $R f$ class 2 , protolichesterinic acid between $R f$ classes 3-4, atranorin at $R f$ class 7 . In Peltigera polydactyla, two compounds were detected such as gyrophoric acid at $R f$ class 3 and tenuiorin at $R f$ class 7 . In lichen Sulcaria sulcata has pulvinic acid at $R f$ class 1 , virensic acid at $R f$ class 3-4, psoromic acid at $R f$ class 4 and vulpinic acid at $R f$ class 6-7 were present.

\section{Antibacterial activity of extracts}

The present study confirmed the presence of antibacterial substance in all the extracts of tested lichens and the results were presented (Table 1). The majority of acetone, methanol and ethanol extracts of $U$. longissima exhibited activity against the gram positive Staphylococcus aureus, Streptococcus faecalis and Bacillus cereus. Importantly the ethanol extract showed activity against two gram negative bacteria, Pseudomonas aeruginosa and E. coli. No activity was recorded against $S$. typhimurium. Against $S$. aureus, the methanol extract was most active with a mean zone of $18.4 \pm 1.4 \mathrm{~mm}$ diameters. Against $S$. faecalis and B. cereus, again the zone of methanol extract was better than acetone and ethanol extract and the mean zone of inhibition was $22.6 \pm 1.4 \mathrm{~mm}$ and $30.7 \pm 0.9 \mathrm{~mm}$ diameters respectively. The activity of ethanol extract against $P$. aeruginosa and $E$. coli was $16.3 \pm 0.5 \mathrm{~mm}$ and $18.8 \pm 0.8 \mathrm{~mm}$ diameters respectively. The inhibitory effect of solvent alone on microorganisms was nil.

E. cirrhatum extracts were active against all the gram positive and a single gram negative bacteria. Against $S$. aureus, the activity of ethanol extract was greater than acetone and methanol extract and the calculated zone of inhibition against ethanol extract was $20.2 \pm 1.1 \mathrm{~mm}$ diameters. The zone of inhibition noted for ethanol extract against $S$. faecalis and B. cereus was $16.3 \pm 0.5 \mathrm{~mm}$ and $24.1 \pm 0.6 \mathrm{~mm}$ diameters respectively. Against $P$. aeruginosa, only ethanol extract was effective and the calculated zone of inhibition was $19.3 \pm 1.1 \mathrm{~mm}$.

Ethanol extract of $P$. polydactylon showed activity against $S$. aureus with a mean zone of $10.8 \pm 0.8 \mathrm{~mm}$ diameters. Both the acetone and ethanol extract showed activity against $S$. faecalis with a mean zone of $9.6 \pm 0.5 \mathrm{~mm}$ and $11 \pm 1.1 \mathrm{~mm}$ diameters respectively. Against $B$. cereus, only ethanol extract was effective with a mean zone of $15.1 \pm 0.7 \mathrm{~mm}$. Only acetone extract shown activity against $P$. aeruginosa with a zone of $7.6 \pm 0.5 \mathrm{~mm}$.

All the three extracts of $S$. sulcata showed activity against $S$. aureus and B. cereus. Against $S$. aureus, the acetone extract was most effective and the calculated zone was $17.1 \pm 0.8 \mathrm{~mm}$ diameters while against $B$. cereus, the zone of acetone extract $(8.7 \pm 1.2 \mathrm{~mm})$ was more than methanol and ethanol extract. Marked activity was shown by ethanol against $P$. aeruginosa and the mean zone of inhibition was $7.6 \pm 0.5 \mathrm{~mm}$ diameters. No activity was noted against $S$. faecalis, $E$. coli and S. typhimurium

\section{Minimum Inhibitory Concentration}

The results of minimum inhibitory concentration of lichen $U$. longissima ranged within the range of $3.125-200 \mu \mathrm{g} / \mathrm{ml}$. The least MIC value was calculated against $B$. cereus $(6.25 \mu \mathrm{g} / \mathrm{ml})$. The MIC results of E. cirrhatum were varying between 3.125-200 $\mu \mathrm{g} / \mathrm{ml}$. Lowest MIC was observed against $S$. faecalis $(12.5 \mu \mathrm{g} / \mathrm{ml})$. The MIC value noted for $P$. polydactylon against all the tested bacteria was $200 \mu \mathrm{g} / \mathrm{ml}$. The MIC value calculated for the extract of $S$. sulcata against all the tested bacteria was $200 \mu \mathrm{g} / \mathrm{ml}$ (Table 2). 
Table1 Results of zone of inhibition (mm) of extracts of Usnea longissima, Everniastrum cirrhatum, Peltigera polydactylon and Sulcaria sulcata against tested microorganisms.

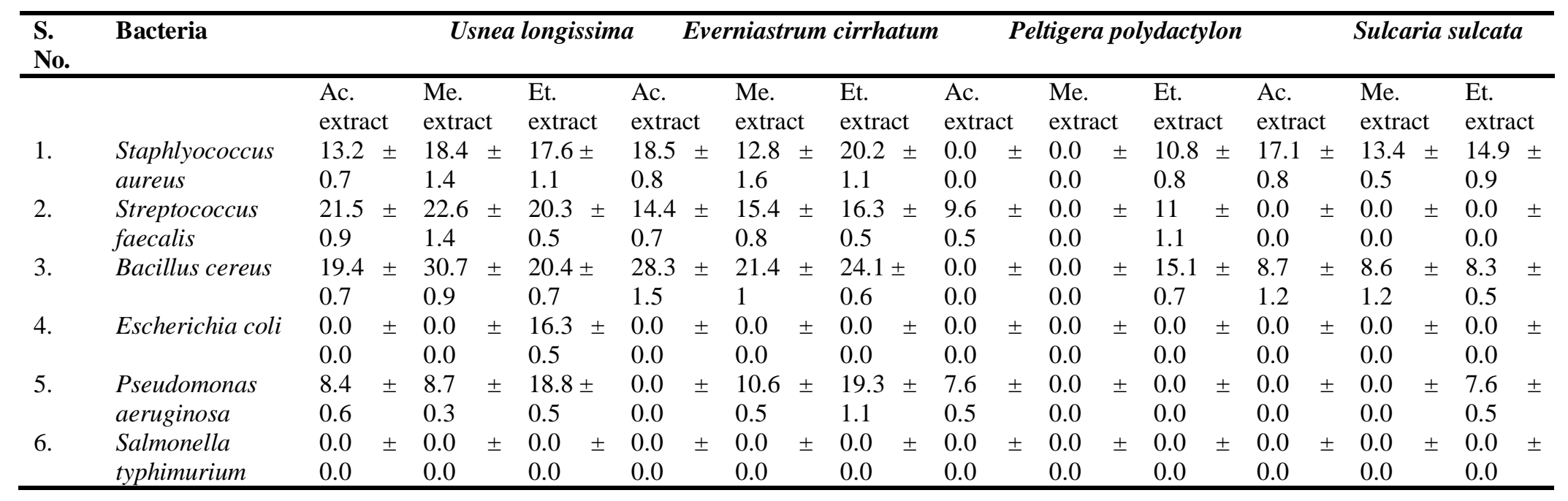

(*values are in mean \pm Standard deviation, $\mathrm{n}=3$ )

$($ Ac. $=$ Acetone, Me. $=$ Methanol, Et. $=$ Ethanol)

Table 2 Results of Minimum Inhibitory Concentration (MIC) of extracts of Usnea longissima, Everniastrum cirrhatum, Peltigera polydactylon and Sulcaria sulcata against tested microorganisms.

\begin{tabular}{|c|c|c|c|c|c|}
\hline \multirow[t]{2}{*}{ S.No } & \multirow[t]{2}{*}{ Bacterial pathogen } & \multicolumn{2}{|c|}{$\begin{array}{l}\text { Lichen Species } \\
(\mathrm{MIC} \text { in } \mu \mathrm{g} / \mathrm{ml})\end{array}$} & \multirow[b]{2}{*}{ Peltigera polydactylon } & \multirow{3}{*}{$\begin{array}{l}\text { Sulcaria sulcata } \\
200\end{array}$} \\
\hline & & Usnea longissima & Everniastrum cirrhatum & & \\
\hline 1. & Staphlyococcus aureus & 3.125 & 3.125 & 200 & \\
\hline 2. & Streptococcus faecalis & 25 & 12.5 & 200 & NA \\
\hline 3. & Bacillus cereus & 6.25 & 3.125 & 200 & 200 \\
\hline 4. & Pseudomonas aeruginosa & 200 & 200 & 200 & 200 \\
\hline 5. & Escherichia coli & 200 & NA & NA & NA \\
\hline
\end{tabular}

$\mathrm{NA}=$ No Activity 


\section{Discussion}

Lichens produce antibiotic secondary metabolites that provide defense against most of the pathogens in nature (Molnar and Farkas 2010). The tested lichen extracts showed a relatively strong antimicrobial activity. The screening results showed that nearly all the extracts of the tested lichens showed antibacterial activity against gram positive as well as gram negative bacteria. Antibacterial activity observed in this present investigation depended on the sort of the extract, its concentration and the tested microorganisms. Similar results were also noticed by other investigators (Rankovic et al. 2007), there is no antibacterial activity of the extracts against $S$. typhimurium was detected. Strong antibacterial activity was given by all the tested lichens against $S$. aureus, but extracts of $E$. cirrhatum showed larger zone of inhibition against this bacterium. Dülger et al. (1997, 1998) have found that although 4 different extracts of a macrofungus have inhibition effect against B. subtilis ATCC 6633 and other some gram positive and negative bacteria, and they do not have effect against E. coli ATCC 11230, S. epidermidis NRRL B-4377, S. aureus ATCC 6538P (Dülger et al. 1998). Activity against $S$. faecalis was given by all the lichens except S. sulcata. Among all the tested lichens, U. longissima was most effective against this bacterium. Rowe et al. (1999) reported that the lichens from Turkey, Evernia prunastri, Pseudovernia furfuracea and Alectoria capillaris were active against gram-positive bacteria and Candida albicans.

$U$. longissima showed the maximum activity against B. cereus. Similar to U. longissima, extracts of E. cirrhatum and $P$. polydactylon were also showing better activity against $B$. cereus. It has been determined that lichens have shown the inhibition effect against a lot of bacteria such as Bacillus, Pseudomonas, E. coli, Streptococcus, Staphylococcus, Enterococcus, Mycobacterium (Esimone and Adikwn 1999, Perry et al. 1999). However, S. sulcata showed poor activity against B. cereus. The previous studies carried out by Burkholder et al. (1944), Rowe et al. (1989) and Silva et al. (1986) indicated that the lichens inhibit mostly gram positive bacteria. Even though most of the lichens have been reported to be active against gram positive bacteria, but it is of great interest to note that the extracts of U. longissima, E. cirrhatum, P. polydactylon and S. sulcata inhibited the growth of gram negative bacteria together with gram positive bacteria. All the extracts of four lichens showed activity against $P$. aeruginosa except $U$. longissima which showed activity against both gram negative bacteria such as $P$. aeruginosa and E. coli.

All the three extracts of $U$. longissima, methanol extract was found to have larger zone of inhibitions while according to Gulluce et al. (2006) and the methanol extract of the lichen Parmelia saxatilis had a strong antimicrobial influence. Results of $U$. longissima are comparable to Thippeswamy et al.(2011) where Ethanol extract of Usnea Longissima exhibited significant antibacterial activity and antifungal activity with $1 \mathrm{mg} / \mathrm{ml}$ Agar well diffusion method against the Gram positive and Gram negative bacteria. Ethanol extracts of E. cirrhatum showed maximum inhibition as compared to acetone and methanol extracts while in the studies done by Swathi et al. (2010), Methanol extract of E. cirrhatum caused more inhibition of Streptococcus epidermidis than other bacteria whereas P. aeruginosa was least inhibited. The MIC was found to be least for S. epidermidis. Similar to Parmelia kamstchandalis tested using disc diffusion method by Mazid et al. (1999). Ethanol extract of both $P$. polydactyla and $S$. sulcata show inhibitory activity against large number of bacteria. According to Burkholder et al. (1944), out of 100 species of American lichens, only $52 \%$ of lichens showed activity against gram positive bacteria. Silva et al. (1986) also observed that most of the Brazilian lichens were active against gram positive bacteria.

In the present study, the extracts showed activity with different MIC values against the same microorganisms. Although the obtained MIC values for all extracts were varying between $6.25-200 \mu \mathrm{g} / \mathrm{ml}$ and for each microorganism. Madamombe and Afolayan (2003) reported significant activity of Usnea barbata against gram positive bacteria with MIC as low as $100 \mu \mathrm{g} / \mathrm{ml}$ on B. subtilis, S. faecalis, M. viridans and S. aureus. However in our study, the MIC value calculated against Usnea longissima was as low as $6.25 \mu \mathrm{g} / \mathrm{ml}$ against B. cereus and S. aureus respectively. 
Both $U$. longissima and E. cirrhatum have a higher activity against gram positive as well as gram negative bacteria. However, $P$. polydactylon and $S$. sulcata were also effective against tested bacteria but the zones of inhibitions were quite smaller. Owing to pronounced antimicrobial activity of some of their secondary metabolites, lichens (along with algae, micro fungi and higher plants) are attracting much attention among researchers as significant new sources of bioactive substance. (Hostettmann et. al. 1997, Ingolfsdottir et al. 1997). Lichen compounds do have antimicrobial property that must be investigated to determine that what compounds are useful and how best to extract them in order to provide some legitimacy to a potential medical goldmine. Hence, there is an interest in the potential uses of antibiotics derived from lichens for the pharmaceutical industry in the future. In addition, the data may also suggest that the extracts of lichen species tested possess compounds with antibacterial properties, which require further studies to determine antimicrobial agents for therapy of infectious diseases in humans.

\section{Acknowledgements}

The authors grateful to The Director, CSIR-National Botanical Research Institute, Lucknow, and the Head, Department of Microbiology, SGPGI, Lucknow and India for providing necessary laboratory facilities to carry out this work. The authors are also grateful to Department of Biotechnology, Government of India for financial support.

\section{References}

Awasthi DD. 2007 - A compendium of the Macrolichens from India, Nepal and Sri Lanka. Bishen Singh Mahendra Pal Singh, Dehra Dun, India.

Bauer AW, Kirby WM, Sherris JC and Turck M. 1966 - Antibiotic Susceptibility testing by a standardized single disk method. American Journal of Clinical Pathology 45, 493-496.

Baytop T. 1999 - Therapy with Medicinal plants in Turkey - Past and Present. Nobel publishers $2^{\text {nd }}$ Edition. Istanbul.

Boustie J and Grube M. 2005 - Lichens - a promising source of bioactive secondary metabolites. Plant Genetic Resources: Characterization and Utilization. 3, 273-287.

Burkholder PR, Evans AW, McVeigh I and Thornton HK. 1944 - Antibiotic activity of lichens. Proceedings on National Academic Science, USA, 30(9), 250-255.

Chand P, Singh M and Rai M. 2009 - Antibacterial activity of some Indian lichens. Journal of ecophysiology and occupational health 9, 23-29

Dayan FE and Romagni RJ. 2001 - Lichens as a potential source of pesticides. Pestic Outlook. 12: 229-232.

Dülger B, Gücin F and Aslan A. 1998 - Cetraria islandica (L.) Ach. Likenin Antimikrobiyal Aktivitesi. Tropical Journal of Biology 22, 111-118.

Dülger B, Gücin F, Kara A and Aslan A. 1997 - Usnea florida (L) Wigg. Likeninin Antimikrobiyal Aktivitesi. Tropical Journal of Biology 21, 103-108.

Elix JA. 1996 - Biochemistry and secondary metabolites. In: Lichen Biology (Nash III T. H., ed.). Cambridge University Press, Cambridge, 154-181.

Esimone, CO and Adikwn MU. 1999 - Antimicrobial activty of the cytotoxicity of Ramalina farinaceae. Fitoterapia 7, 428-431.

Galun M. 1988 - CRC Handbook of Lichenology. CRC Press, Boca Raton, Florida.

Gulluce M, Aslan A, Sokmen M, Sahin F, Adiguzel A, Agar G and Sokmen A. 2006 - Screening the antioxidant and antimicrobial properties of the lichens Parmelia saxatilis, Platismatia glauca, Ramalina pollinaria, Ramalina polymorpha and Umbilicaria nylanderiana. Phytomedicine 13, 515-521.

Halama P and van Haluwin C. 2004 - Antifungal activity of lichen extracts and lichenic acids. biocontrol 49, 95-107. 
Hostettmann K, Wolfender JL and Rodriguez S. 1997 - Rapid detections and subsequent isolation of bioactive constituents of crude plant extracts, Planta Medica 63(1), 2-10.

Huneck S. 1999 - The significance of lichens and their metabolites. Naturwissenschaften 86, 559576.

Ingolfsdottir K, Halmarsdottir MA, Guojonsdottir GA, Brynjolfsdottir A, Sigurdsson A and SteinGrimsson O. 1997 - In vitro susceptibility of Helicobacter pylori to protolichesterinic acid from Cetraria islandica. Antimicrobial Agents Chemotherapy 41, 215-217.

Kirmizigül S, Koz Ö, Anil H and Içli S. 2003. - Isolation and structure elucidation of novel natural products from Turkish lichens. Turkish Journal of Chemistry 27, 493-500.

Lawrey JD. 1986 - Biological role of lichen substances. Bryologist 89, 111-122.

Madamombe IT and Afolayan AJ. 2003 - Evaluation of antimicrobial activity of extracts from South African Usnea barbata. Pharmaceutical biology 41(3), 199-202.

Mazid MA, Hasan CM and Rashi MA. 1999 - Antibacterial activity of Parmelia kamstchandalis. Fitoterapia. 70, 615-617.

Molnar K and Farkas E. 2010 - Current Results on Biological Activities of Lichen Secondary Metabolites: a Review. Z Naturforsch. 65c: 157-173.

Muller K. 2001 - Pharmaceutically relevant metabolites from lichens. Appl Microbiol Biotechnol. 56: 9-16.

NCCLS. 1993 - Performance standards for antimicrobial disk susceptibility tests. 1993. Approved standard. NCCLS document M2-A5. Wayne, Pa.

NCCLS. 2002 - Performance standards for antimicrobial susceptibility testing. Twelfth informational supplement. NCCLS document M100-S12. NCCLS Wayne, Pa.

Orange A, James PW, White FJ. 2001 - Microchemical Methods for the Identification of Lichens. London, British Lichen Society.

Ötzürk S, Güvenç S, Arikan N and Yýlmaz Ö. 1999 - Effect of usnic acid on mitotic index in root tips of Allium cepa L. Lagascalia. 21, 47-52.

Perry NB, Benn MH, Brennan NJ, Burgess EJ, Ellis G, Galloway DJ, Lorimer SD and Tangney S. 1999 - Antimicrobial, antiviral and cytotoxic activity of New Zeland lichens. Lichenologist 31, 627-636.

Rankovic B, Mišic M, Sukdolak S and Milosavljevic D. 2007 - Antimicrobial activity of the lichen Aspicilia cinerea, Collema cristatum, Ochrolechia androgyna, Physcia aipolia and Physcia caesia. Italian journal of food science 4, 461-469.

Richardson DHS. 1988 - Medicinal and other economic aspects of lichens. In: Galun M ed. CRC Handbook of lichenology. Boca Raton, Florida, CRC Press pp. 93-108

Richardson DHS. 1991 - Lichen and man. In: Hawksworth DL., ed. Frontiers in Mycology. Wallingford, CAB International pp. 187-210.

Romagni JG and Dayan FE. 2002 - Structural diversity of lichen metabolites and their potential use, in Advances in Microbial Toxin Research and its Biotechnological Exploitation, Upadhyay RK Ed., New York. Kluwer Academic, Plenum Publishers pp. 151-169.

Rowe JG, Garcia MD, Saenz Rodriguez MT. 1999 - Some lichen products have antimicrobial activity. Zeitschrift für Naturforschung 54(7-8), 605-609.

Rowe JG, Saenz MT, Garcia MD. 1989 - Contribution a a'l e' tudedel' activiteantibacterienne de queques lichens du sudde l'Espagne. Pharmaceutical francaise 47, 89-94.

Santos P and Mondragon A. 1969 - Studies on the Philippine lichens, II thin-layer chromatographic study of the constituents of some lichen species. Philippines Journal of Sciences 98, 297-303.

Sharnoff SD. 1997 - Lichens and people. Online:http://www.lichen.com/people.html

Silva DA, Oliveira J, Maileite JE, Paulo MQ and Filho LX. 1986 - Antimicrobial activity of Brazilian lichens. Biological Society Broteriana. 59(C), 87-96.

Swathi D, Suchitha Y, Prashith Kekuda TR, Venugopal TM, Vinayaka KS, Mallikarjun N, Raghavendra HL. 2010 - Antimicrobial, Anthelmintic And Insecticidal Activity Of A Macrolichen Everniastrum cirrhatum (Fr.) Hale. Int. J. Drug Dev. \& Res. 2(4):780-789 
Tay T, Özdemir TA, Yilmaz M, Türk H and Kivanc M. 2004 - Evolution of the antimicrobial activity of the acetone extract of the lichen Ramalina farinacea and its (+) - usnic acid, norstictic acid, and protocetraric acid constituents. Zeitschrift für Naturforschung 59, 384388.

Thippeswamy B, Naveenkumar KJ, Bodharthi JG and Shivaprasad SR. 2011 - Antimicrobial activity of ethanolic extract of Usnea longissima. Journal of Experimental Sciences 2(12): 01-03

Tiwari P, Rai H, Upreti DK, Trivedi S, Shukla P. 2011a - Assessment of antifungal activity of some himalayan foliose lichens against plant pathogenic fungi. American Journal of Plant Sciences 2: 841-846.

Tiwari P, Rai H, Upreti DK, Trivedi S, Shukla P. 2011b - Antifungal Activity of a Common Himalayan Foliose Lichen Parmotrema tinctorum ( Despr. ex Nyl.) Hale. Nature and Science 9(9): 167-171 